\title{
Effectiveness of harmonic scalpel in patients submitted to total thyroidectomy: systematic review with meta-analysis
}

\author{
(iD) Felipe Toyama Aires ${ }^{1}$ \\ Leandro Luongo de Matos ${ }^{2}$ \\ Rogério Aparecido Dedivitis ${ }^{3}$ \\ Claudio Roberto Cernea ${ }^{4}$
}

\begin{abstract}
1. Assistant, Department of Head and Neck Surgery, Hospital das Clinicas, University of São Paulo School of Medicine, São Paulo/São Paulo, Brasil 2. Full Professor, Assistant, Department of Head and Neck Surgery, Instituto do Cancer do Estado de Sao Paulo (ICESP), São Paulo/São Paulo, Brasil 3. Full Professor, Assistant, Department of Head and Neck Surgery, Hospital das Clinicas, University of São Paulo School of Medicine, São Paulo/São Paulo, Brasil 4. Full Professor, Head of Department of Head and Neck Surgery, Hospital das Clinicas, University of São Paulo School of Medicine, São Paulo/São Paulo, Brasil
\end{abstract}

http://dx.doi.org/10.1590/1806-9282.64.07.649

\section{SUMMARY}

OBJECTIVE: The objective of this study was to evaluate the efficacy and safety of the harmonic scalpel compared to the conventional technique in patients submitted to total thyroidectomy.

METHOD: This is a systematic review with inclusion of randomized controlled trials ( $R C T s$ ) that compared both techniques. An electronic search was carried out in the Medline and Lilacs databases until June 2017. The outcomes analysed were operation time, intraoperative bleeding, surgical morbidity, and costs.

RESULTS: Data from 31 primary studies were included. The use of the harmonic scalpel correlates to a shorter operation time $(p<0.001)$ and a lower volume of intraoperative bleeding $(p<0.001)$. There were no differences in the risk of transient $(p=0.53)$ and permanent $(p=$ $0.70)$ hypocalcaemia, transient $(p=0.61)$ and permanent $(p=0.50)$ dysfunctions of the inferior laryngeal nerve and hematoma $(p=0.14)$. CONCLUSION: Total thyroidectomy using a harmonic scalpel is effective and safe compared to the conventional technique. KEYWORDS: Thyroidectomy. Haemostasis, surgical/methods. Ultrasonic surgical procedures. Review.

\section{INTRODUCTION}

Thyroidectomy is the most performed operation by head and neck surgeons and is considered a safe procedure, with virtually no mortality. Due to the rich vascularization of the thyroid gland, its resection is based on haemostasis both to prevent bleeding that can become fatal and to keep the surgical field clean and facilitate the visualization of noble structures such as the laryngeal nerves and the parathyroid glands ${ }^{1,2}$.

In order to provide bleeding control, haemostatic devices have been developed to try to make the operation even safer. One of the most studied is the harmonic (or ultrasonic) scalpel, which consists of the use of high frequency wave that is converted into mechanical energy and simultaneously promotes the sealing and sectioning of blood vessels, as well as fibrous and muscular tissue structures, providing adequate haemostasis at temperatures lower than those of mono- and bipolar scalpels ${ }^{3,4}$.

The objective of this study was to perform a systematic review to evaluate the efficacy and safety of the harmonic scalpel compared to the conventional technique in patients submitted to total thyroidectomy. 


\section{METHOD}

\section{Selection criteria}

We selected all randomized and controlled clinical trials comparing the use of harmonic scalpel with the conventional ligature technique in patients submitted to total thyroidectomy. The studies were selected from the reading of the respective titles and abstracts. When it was not possible to identify whether the study would be included or not, the full text was requested for the detailed analysis.

Studies that included patients with thyroid gland disease, regardless of the nature of the diagnosis (benign or malignant), who underwent total thyroidectomy were included. Studies that included patients submitted to total thyroidectomy, associated with other concomitant procedures, and with a history of previous surgery and/or cervical irradiation were excluded.

The intervention group included patients who used the harmonic scalpel during the surgical procedure, while the control group underwent conventional ligation surgery. At first, there was no restriction on the description of the harmonic scalpel technology used.

The outcomes analysed were operating time, intraoperative bleeding volume, incidences of inferior laryngeal nerve injury (temporary and permanent), hypocalcaemia (temporary and permanent), and hematoma requiring surgical intervention and procedure costs.

\section{SEARCH STRATEGY}

The electronic databases Medline (via PubMed) and Lilacs were consulted for identification of the primary studies. These were closed in June 2017.

For the recovery of the primary articles, the search strategy (thyroidectomy OR thyroid surgery) AND (electrocoagulation OR ultrasonic surgical procedures OR ligation OR constriction OR surgical haemostasis OR suture techniques OR harmonic OR ultrasonic OR surgical instruments OR) was used.

In addition, the references of the selected studies and of published reviews were consulted through manual search to select articles that were not included in the electronic searches.

\section{STATISTICAL ANALYSIS}

The measures of effectiveness or damage expressed in absolute numbers were analysed through the relative risk difference adopting a 95\% confidence interval. For all statistically significant results, the numbers needed to treat (NNT) and numbers needed to harm $(\mathrm{NNH})$ were calculated. The continuous data were analysed when the average and its standard deviation of the final measurements were presented. The weighted average difference between groups was used.

Inconsistencies between clinical trials were estimated by the chi-square test $\left(\mathrm{Chi}^{2}\right)$ of heterogeneity and quantified using the $\mathrm{I}^{2}$ test. Values above 50\% were considered as high heterogeneity.

A sensitivity analysis was carried out regarding the methodological risk, which was established according to the Jadad criteria ${ }^{5}$.

\section{RESULTS}

\section{Results of electronic searches}

Electronic and manual searches resulted in a total of 2,137 studies. After reading the respective titles and abstracts, 2,099 studies that clearly did not fit the proposed theme were excluded. Thirty-eight studies potentially eligible for inclusion were selected for reading the full texts. After this step, seven studies were excluded, since four did not separately describe the results regarding total and partial thyroidectomy $^{6-9}$, one was not a randomized clinical tri$\mathrm{al}^{10}$, one was published in duplicate ${ }^{11}$ (the most recent article was considered) and one included only $7 \%$ of the sample submitted to total thyroidectomy ${ }^{12}$. Thus, the results of this review are based on data from 31 studies.

\section{Assessment of methodological risk of primary studies}

All primary studies were described as a randomized clinical trial. Of the 31 studies, only ten adequately described the randomization and al-

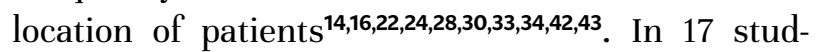
ies the method of randomization was not describ ed $^{15,17-20,25,26,27,29,31,32,35-39,41}$ and in another four it was considered inappropriate ${ }^{13,21,23,40}$.

Since it is a surgical study, double blinding is very difficult to apply. Only one study was described as

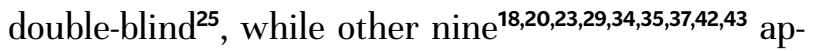
plied blinding only in the patients. In the remaining 21 studies, there was no blinding.

Whenever present, loss of follow-up or protocol break were described, and accounted for less than $20 \%$ in all studies. 
FIGURE 1. META-ANALYSIS ON (A) OPERATION TIME AND (B) INTRAOPERATIVE BLEEDING COMPARING THE HARMONIC SCALPEL WITH THE CONVENTIONAL TECHNIQUE.

\begin{tabular}{|c|c|c|c|c|c|c|c|c|c|c|}
\hline \multirow{3}{*}{$\begin{array}{l}\text { Study or Subgroup } \\
\text { A-Dhahiry, } 2015\end{array}$} & \multicolumn{3}{|c|}{ Harmonic } & \multicolumn{3}{|c|}{ Conventional } & \multirow{3}{*}{$\begin{array}{r}\text { Weight } \\
3.8 \%\end{array}$} & \multirow{3}{*}{$\begin{array}{l}\text { Mean Difference } \\
\text { IV, Random, 95\% a } \\
-20.00[-26.52,-13.48]\end{array}$} & \multirow{2}{*}{\multicolumn{2}{|c|}{$\begin{array}{l}\text { Mean Difference } \\
\text { IV, Random, 95\% a }\end{array}$}} \\
\hline & \multirow{2}{*}{$\begin{array}{r}\text { Mean } \\
93\end{array}$} & \multirow{2}{*}{$\begin{array}{l}\text { SD } \\
13\end{array}$} & \multirow{2}{*}{$\begin{array}{r}\text { Total } \\
26\end{array}$} & \multirow{2}{*}{$\begin{array}{r}\text { Mean } \\
113\end{array}$} & \multirow{2}{*}{$\begin{array}{r}\text { SD } \\
10.9\end{array}$} & \multirow{2}{*}{$\begin{array}{r}\text { Total } \\
26\end{array}$} & & & & \\
\hline & & & & & & & & & $\rightarrow$ & \\
\hline Arsan, 2017 & 92.3 & 8.7 & 101 & 96.7 & 10.4 & 105 & $4.0 \%$ & $-4.40[-7.01,-1.79]$ & च & o \\
\hline Blanchard, 2017 & 97 & 39 & 606 & 107 & 46 & 595 & $3.9 \%$ & $-10.00[-14.83,-5.17]$ & $\sigma$ & \\
\hline Cannizzaro, 2014 & 79.4 & 21.9 & 141 & 110 & 25.8 & 124 & $3.9 \%$ & $-30.60[-36.40,-24.80]$ & $\sigma$ & \\
\hline Cordon, 2005 & 104 & 29 & 7 & 136 & 37 & 12 & $2.0 \%$ & $-32.00[-62.00,-2.00]$ & & \\
\hline Defechereux, 2003 & 70.7 & 18.3 & 17 & 96.5 & 28.9 & 17 & $3.1 \%$ & $-25.80[-42.06,-9.54]$ & $=$ & \\
\hline Di Fenzo, 2010 & 62.7 & 14.1 & 31 & 72.7 & 13.6 & 31 & $3.8 \%$ & $-10.00[-16.90,-3.10]$ & $\rightarrow$ & \\
\hline Docimo, 2012 & 63 & 9 & 100 & 85 & 15 & 100 & $4.0 \%$ & $-22.00[-25.43,-18.57]$ & $\sigma$ & \\
\hline Duan, 2013 & 79 & 21.5 & 389 & 125 & 30.4 & 389 & $4.0 \%$ & $-46.00[-49.70,-42.30]$ & $\pi$ & \\
\hline Ferri, 2011 & 44.9 & 8.3 & 50 & 69.5 & 10.7 & 50 & $4.0 \%$ & $-24.60[-28.35,-20.85]$ & $\Psi$ & \\
\hline Frazzetta, 2005 & 56 & 18 & 60 & 96 & 17 & 60 & $3.9 \%$ & $-40.00[-46.26,-33.74]$ & & \\
\hline Gentileschi, 2011 & 100 & 34 & 43 & 119 & 30 & 38 & $3.3 \%$ & $-19.00[-32.94,-5.06]$ & $=$ & \\
\hline Konturek, 2012 & 45.4 & 8.7 & 41 & 64.5 & 14.2 & 41 & $3.9 \%$ & $-19.10[-24.20,-14.00]$ & 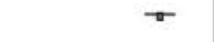 & \\
\hline Kowalski, 2012 & 72.6 & 33.9 & 128 & 87.8 & 40.3 & 133 & $3.7 \%$ & $-15.20[-24.22,-6.18]$ & $\varpi$ & \\
\hline Lombardi, 2008 & 53.1 & 20.7 & 100 & 75.2 & 23.5 & 100 & $3.9 \%$ & $-22.10[-28.24,-15.96]$ & $\rightarrow$ & \\
\hline Materazi, 2013 & 51.9 & 30.3 & 141 & 70.9 & 34.8 & 127 & $3.8 \%$ & $-19.00[-26.85,-11.15]$ & 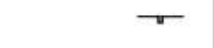 & \\
\hline Micooli, 2006 & 40 & 6.8 & 50 & 46.7 & 10.8 & 50 & $4.0 \%$ & $-6.70[-10.24,-3.16]$ & $\pi$ & \\
\hline Minni. 2016 & 78.8 & 16.1 & 174 & 133.6 & 33.4 & 187 & $3.9 \%$ & $-54.80[-60.15,-49.45]$ & 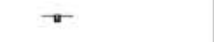 & \\
\hline Mourad, 2011 & 57 & 13 & 34 & 80 & 12 & 34 & $3.9 \%$ & $-23.00[-28.95,-17.05]$ & $=$ & \\
\hline Ortega, 2004 & 86 & 20 & 57 & 101 & 16 & 57 & $3.8 \%$ & $-15.00[-21.65,-8.35]$ & 7 & \\
\hline Papavramidis, 2010 & 76.7 & 22.9 & 45 & 101.7 & 20.8 & 45 & $3.7 \%$ & $-25.00[-34.04,-15.96]$ & $\hookrightarrow$ & \\
\hline Pons, 2009 & 114 & 9 & 20 & 151 & 15 & 20 & $3.8 \%$ & $-37.00[-44.67,-29.33]$ & $\rightarrow$ & \\
\hline Sartori, 2008 & 94 & 24 & 50 & 118 & 28 & 50 & $3.6 \%$ & $-24.00[-34.22,-13.78]$ & $\because$ & \\
\hline Ssta, 2012 & 91 & 37 & 119 & 121 & 42 & 122 & $3.6 \%$ & $-30.00[-39.99,-20.01]$ & 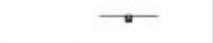 & \\
\hline Soroush, 2013 & 60 & 9.2 & 33 & 121.9 & 30.9 & 35 & $3.6 \%$ & $-61.90[-72.61,-51.19]$ & $\because$ & \\
\hline Yldirim. 2008 & 77.9 & 12.5 & 50 & 105 & 16 & 54 & $3.9 \%$ & $-27.10[-32.60,-21.60]$ & $\sigma$ & \\
\hline Zanghi, 2014 & 105 & 27 & 41 & 143 & 32 & 42 & $3.4 \%$ & $-38.00[-50.73,-25.27]$ & & \\
\hline Total $(95 \%$ d) & & & 2654 & & & 2644 & $100.0 \%$ & $-25.76[-31.60,-19.91]$ & & \\
\hline Heterogeneity: Tau & $220.05:$ & $\mathrm{Ch}^{2}=$ & 719.08 & $d f=26$ & $(P<0$. & .00001 & 1): $1^{2}=96^{\circ}$ & & $\begin{array}{cc}1 & 1 \\
-50 & -25\end{array}$ & $\begin{array}{ll}1 & 1 \\
0 & 25\end{array}$ \\
\hline Test for overall effect & $Z=8.64$ & $(P<0$ & $.00001)$ & & & & & & Favours Harmonic & Favours Conventional \\
\hline
\end{tabular}

\begin{tabular}{|c|c|c|c|c|c|c|c|c|c|c|c|}
\hline \multirow{3}{*}{$\begin{array}{l}\text { Sudy or Subgroup } \\
\text { Defechereux, } 2003\end{array}$} & \multicolumn{3}{|c|}{ Harmonic } & \multicolumn{3}{|c|}{ Conventional } & \multicolumn{2}{|r|}{ Mean Difference } & \multirow{2}{*}{\multicolumn{3}{|c|}{$\begin{array}{l}\text { Mean Difference } \\
\text { IV, Fixed, } 95 \% \text { a }\end{array}$}} \\
\hline & \multirow{2}{*}{$\begin{array}{r}\text { Mean } \\
74.5\end{array}$} & \multirow{2}{*}{$\frac{S D}{50.9}$} & \multirow{2}{*}{$\begin{array}{r}\text { Total } \\
17\end{array}$} & \multirow{2}{*}{$\begin{array}{l}\text { Mean } \\
134.6\end{array}$} & \multirow{2}{*}{$\frac{\text { SD }}{108.4}$} & \multirow{2}{*}{$\begin{array}{r}\text { Total } \\
17\end{array}$} & \multirow{2}{*}{$\begin{array}{r}\text { Weight } \\
0.2 \%\end{array}$} & \multirow{2}{*}{$\begin{array}{r}\text { IV, Fixed, 95\% a } \\
-60.10[-117.03,-3.17]\end{array}$} & & & \\
\hline & & & & & & & & & & & \\
\hline Frazzetta, 2005 & 40 & 10 & 60 & 100 & 30 & 60 & $11.5 \%$ & $-60.00[-68.00,-52.00]$ & & 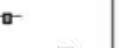 & \\
\hline Konturek, 2012 & 29.9 & 9.8 & 41 & 56.8 & 11 & 41 & $36.2 \%$ & $-26.90[-31.41,-22.39]$ & & 口 & \\
\hline Mourad, 2011 & 28 & 30 & 34 & 52 & 29 & 34 & $3.7 \%$ & $-24.00[-38.03,-9.97]$ & & $\varpi$ & \\
\hline Pons, 2009 & 23 & 19 & 20 & 39 & 19 & 20 & $5.3 \%$ & $-16.00[-27.78,-4.22]$ & & $\rightarrow$ & \\
\hline Sartori, 2008 & 97 & 19 & 50 & 107 & 25 & 50 & $9.7 \%$ & $-10.00[-18.70,-1.30]$ & & $\rightarrow$ & \\
\hline Soroush, 2013 & 24.5 & 6 & 33 & 110.6 & 19.7 & 35 & $15.7 \%$ & $-86.10[-92.94,-79.26]$ & + & & \\
\hline Yldirim, 2008 & 25.3 & 10.2 & 50 & 59.5 & 33.9 & 54 & $8.2 \%$ & $-34.20[-43.67,-24.73]$ & & 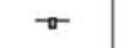 & \\
\hline Zanghi, 2014 & 24 & 18 & 41 & 36 & 23 & 42 & $9.4 \%$ & $-12.00[-20.87,-3.13]$ & & $\rightarrow$ & \\
\hline Total $(95 \%$ a) & & & 346 & & & 353 & $100.0 \%$ & $-36.97[-39.69,-34.26]$ & & 1 & \\
\hline Heterogeneity: Chi & $332.90, \mathrm{c}$ & $\mathrm{df}=8$ & $(P<0.0$ & D0001); & ${ }^{2}=98 \%$ & & & & -100 & $\begin{array}{ll}1 & 1 \\
-50 & 0\end{array}$ & $50 \quad 100$ \\
\hline Test for overall effec & $Z=26.7$ & $1(P<$ & 0.0000 & & & & & & Favours & Harmonic $F$ & surs Conventional \\
\hline
\end{tabular}




\section{Operation time}

Twenty-seven primary studies evaluated the operation time of total thyroidectomy comparing the harmonic scalpel to the conventional technique. Two studies did not provide the standard deviations of the averages and were not included in the overall analysis of the result.

For the calculation of the meta-analysis the random effect method was used due to the high heterogeneity of the results $\left(I^{2}=96 \%\right)$. Patients submitted to total thyroidectomy with the aid of the harmonic scalpel showed a reduction of approximately 26 minutes in the operation time when compared to the conventional group (95\% CI 19.91 to 31.60 , p <0.001, Figure 1A).

\section{Volume of intraoperative bleeding}

Ten primary studies evaluated the intraoperative bleeding volume of total thyroidectomy comparing the harmonic scalpel to the conventional technique. One study was excluded because it did not present the standard deviations of the averages ${ }^{22}$. All studies showed a statistically significant reduction in bleeding volume in the group submitted to thyroidectomy with the aid of a harmonic scalpel. The overall analysis results in a decrease of approximately $35 \mathrm{ml}$ of bleeding (95\% CI 16.31 to 54.35, p <0.001, Figure 1B).

\section{Incidence of postoperative complications}

Hematoma requiring surgical revision was studied in 18 primary studies presenting an incidence of $0.83 \%, 13$ cases $(0.60 \%)$ in the harmonic scalpel group and 23 cases $(1.06 \%)$ in the conventional group. There was no significant difference between the groups (95\% CI -0.01 to $0.00, p=0.14$ and $\mathrm{I}^{2}=0 \%$ ).

The incidence of transient inferior laryngeal nerve dysfunction (24 studies) occurred in 200 patients, 104 cases (4.1\%) in the harmonic scalpel group and 96 cases (3.9\%) in the conventional group. There was no significant difference between the groups (95\% CI -0.01 to 0.01, $\mathrm{p}=0.61$ and $\mathrm{I}^{2}=0 \%$, Figure 2A). In relation to permanent dysfunction (19 studies), there was also no significant difference between the groups $(0.6 \%$ x $0.4 \%, 95 \%$ CI --0.00 to $0.01, p=0.50$ and $\mathrm{I}^{2}=0 \%$, Figure $2 \mathrm{~B}$ ).

Transient hypocalcaemia (25 studies) occurred in $15.3 \%$. In the group with harmonic scalpel, the incidence was $14.9 \%$, while in the conventional group it was $15.6 \%$. There was no significant difference between the groups (95\% CI -0.04 to 0.02, p = 0.40 and $\mathrm{I}^{2}=56 \%$, Figure 2C). Excluding the primary studies responsible for the high heterogeneity $\left(\mathrm{I}^{2}=56 \%\right)^{18,21,29}$, the same effect of the previous analysis was maintained (95\% CI -0.03 to 0.01, $\mathrm{p}=0.53$ and $\mathrm{I}^{2}=0 \%$ ).

TABLE 1. DESCRIPTION OF PROCEDURES COSTS COMPARING TOTAL THYROIDECTOMY WITH AND WITHOUT THE USE OF HARMONIC SCALPEL

\begin{tabular}{|c|c|c|c|c|c|}
\hline Study & Expenses considered & Harmonic & Conventional & $\begin{array}{l}\text { Difference be- } \\
\text { tween averages }\end{array}$ & $\mathrm{p}$ \\
\hline Ortega, $2004^{*}$ & $\begin{array}{l}\text { Medications; Operating room time; } \\
\text { Materials; Hospitalization period }\end{array}$ & $985.77 \pm 107.08$ & $1,148.40 \pm 153.25$ & -162.6 & $<0.001$ \\
\hline Frazzetta, 2005* & $\begin{array}{l}\text { Materials; Operating room time; Medi- } \\
\text { cations; Human Resources }\end{array}$ & $978.6 \pm 120$ & $1,328.7 \pm 105.7$ & -350.1 & $<0.001$ \\
\hline Lombardi, 2008* & $\begin{array}{l}\text { Human Resources; preoperative tests; } \\
\text { Medications; Operating room time; } \\
\text { Materials; Admission/Discharge }\end{array}$ & $2.238 .1 \pm 406.5$ & $2,368.1 \pm 489.9$ & -130.0 & 0.04 \\
\hline Hallgrimsson, 2008* & Materials; Operating room time & $2,040(1,614-3,214)$ & $2,413(922-3,798)$ & -373.0 & - \\
\hline Pons, 2009\# & $\begin{array}{l}\text { Materials; Human Resources; Medica- } \\
\text { tions }\end{array}$ & $2,486 \pm 153$ & $2,571 \pm 296$ & -85.0 & 0.25 \\
\hline Ruggeri, 2012* & $\begin{array}{l}\text { Medications; Operating room time; Ma- } \\
\text { terials; Hospitalization period; Human } \\
\text { Resources; Admission/Discharge }\end{array}$ & $2,292.52$ & $2,411.49$ & -118.9 & - \\
\hline Kowalski, 2012\# & $\begin{array}{l}\text { Operating room time; Materials; Medi- } \\
\text { cations; Hospitalization time }\end{array}$ & $2,554.7 \pm 525.1$ & $2,470.1 \pm 923.9$ & +84.6 & 0.36 \\
\hline Konturek, 2012* & $\begin{array}{l}\text { Operating room time; Materials; Hospi- } \\
\text { talization time }\end{array}$ & $666.2 \pm 32.1$ & $718 \pm 27.2$ & -51.8 & $<0.001$ \\
\hline Blanchard, 2017* & $\begin{array}{l}\text { Operating room time; Hospitalization } \\
\text { period; Human Resources; Materials }\end{array}$ & $3,954 \pm 792$ & $3,728 \pm 831$ & +226 & $<0.001$ \\
\hline
\end{tabular}

Values in euros; \# Values in US dollars 


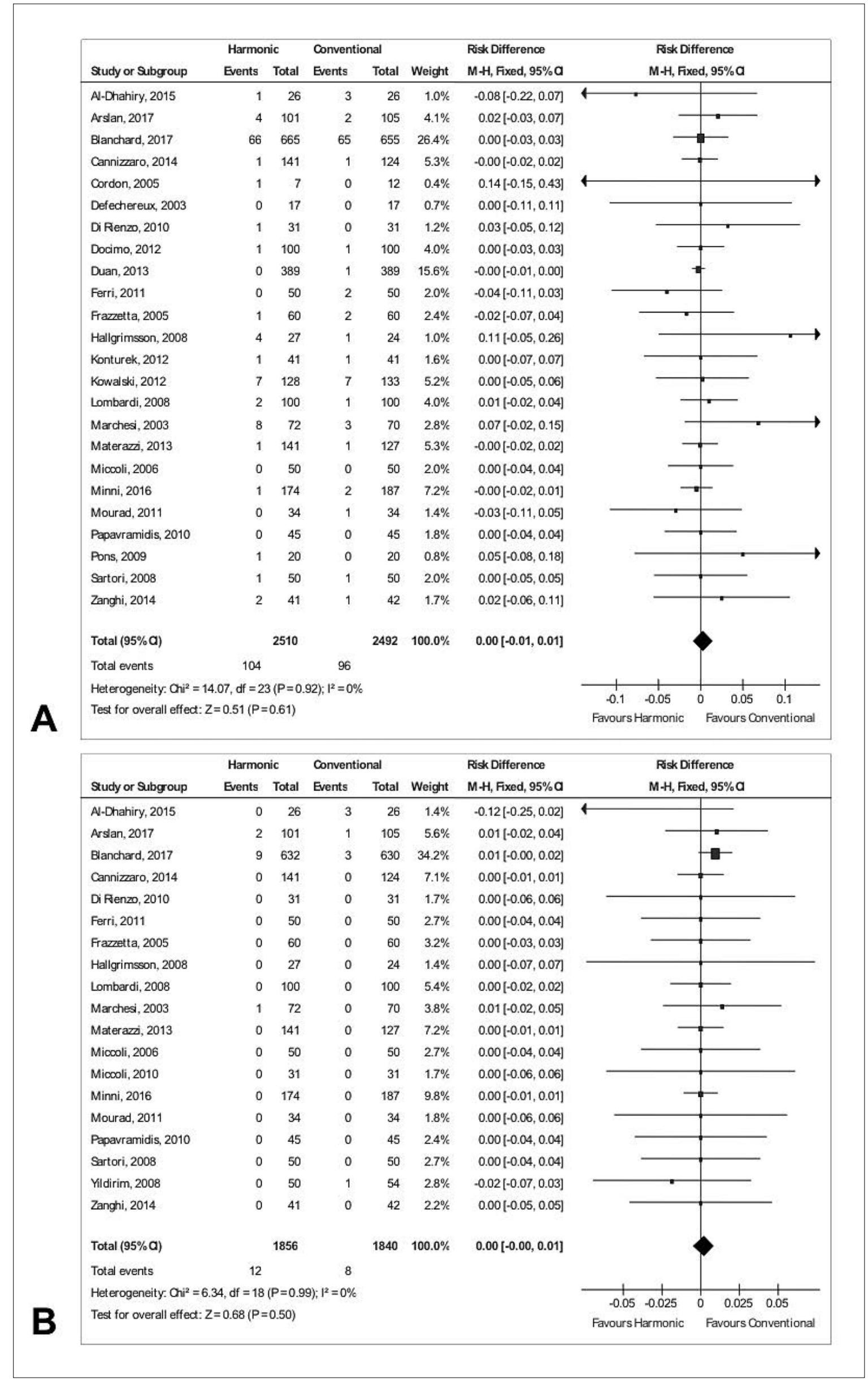




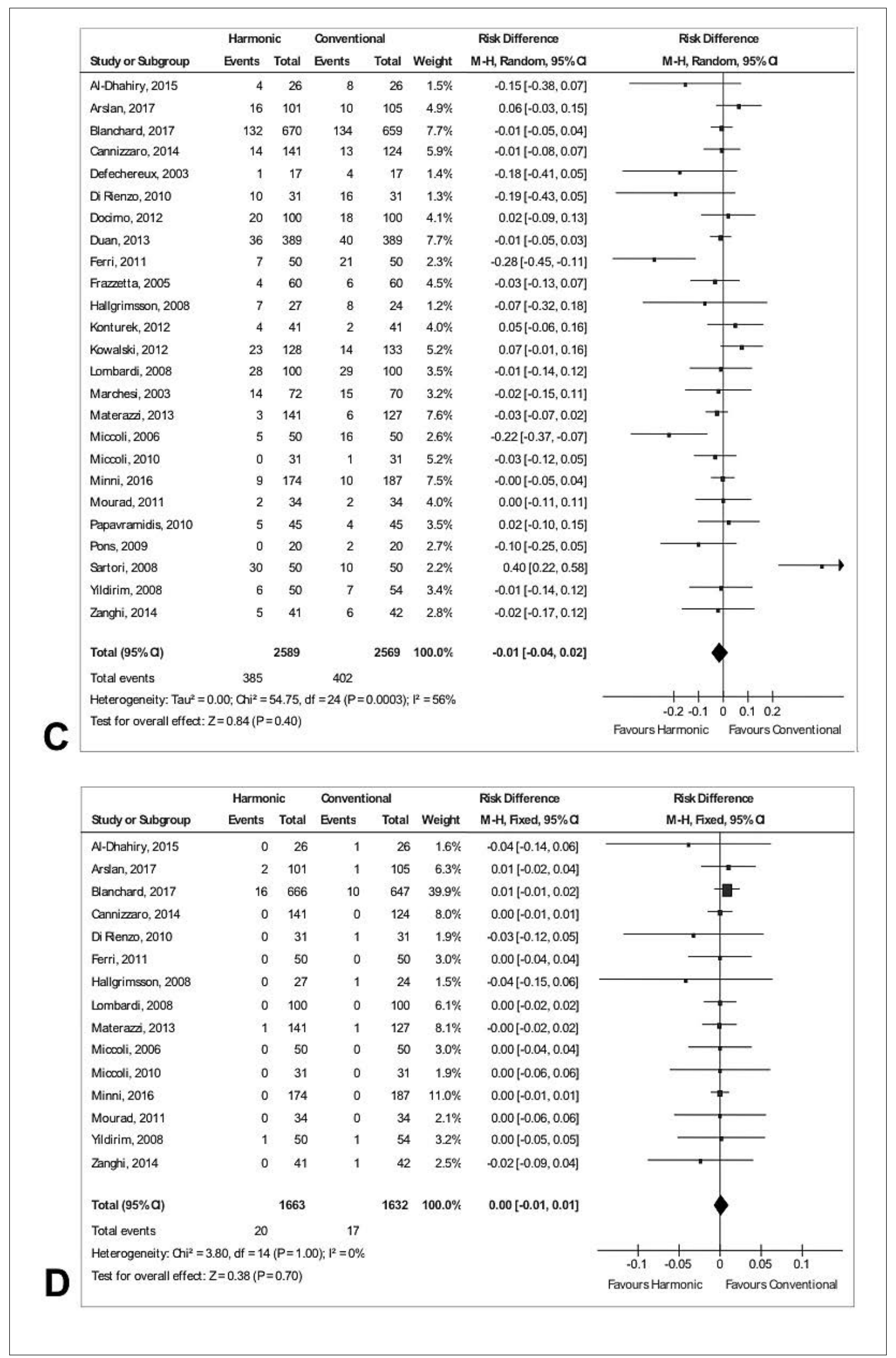

FIGURE 2. META-ANALYSIS ON POSTOPERATIVE COMPLICATIONS COMPARING THE HARMONIC SCALPEL WITH THE CONVENTIONAL TECHNIQUE. A) TEMPORARY DYSFUNCTION OF THE RLN; B) PERMANENT DYSFUNCTION OF THE RLN; C) TRANSIENT HYPOCALCAEMIA; D) PERMANENT HYPOCALCAEMIA. 
Regarding permanent hypocalcaemia, there were no significant differences between groups $(1.2 \%$ x $1.0 \%$, $95 \%$ CI -0.01 to $0.01, p=0.70$ and $\mathrm{I} 2=0 \%$, Figure $2 \mathrm{D}$ ).

\section{COST ASSESSMENT}

Nine primary studies assessed the costs of the treatments comparing the use of the harmonic scalpel to the conventional technique. Data is shown in Table 1. Two studies did not provide the values of standard deviations and were not analyzed ${ }^{22,33}$. Four studies showed a significant decrease in hospital costs, $, 15,17,20,34$ in one study there was a significant increase in $\operatorname{costs}^{43}$ and in two others ${ }^{23,30}$ there was no difference between the groups.

\section{Sensitivity analysis}

A sensitivity analysis was performed for all outcomes related to the methodological risk of primary articles, excluding those at high risk. There was a significant difference in operation time (17.3 minutes, $\mathrm{p}<0.001)$ and intraoperative bleeding volume $(-26.8$ $\mathrm{ml} ; \mathrm{p}<0.001)$ in the group of patients submitted to surgery using a harmonic scalpel. There was no significant difference in the incidence of hematoma $(p=$ $0.16)$, permanent and temporary paralysis $(p=0.66$ and $p=0.10$, respectively) and transient and permanent hypocalcaemia $(p=0.33$ and $p=0.31)$.

\section{DISCUSSION}

Since the first thyroidectomy documented by Abu al-Qasim in 952, until the mid-19 $9^{\text {th }}$ century, with the experience of Theodor Billroth, surgery on the thyroid gland was considered virtually prohibitive ${ }^{1,2}$. It was only at the beginning of the $20^{\text {th }}$ century, with the improvement of anaesthetic and aseptic techniques and a better knowledge of haemostatic techniques, that Emil Theodore Kocher obtained satisfactory results, making thyroidectomy a safe surgery, with mortality around $0.5 \%$. Since then, the surgical technique has changed very little ${ }^{1,2}$.

The success of thyroid surgery is primarily based on adequate haemostasis both to prevent bleeding, which can become fatal, and to keep the surgical site clean and facilitate dissection of tissues, especially vital structures such as the lower laryngeal nerve and parathyroid glands. Given this premise, the results of this review show that there is a statistically significant decrease in intraoperative bleeding volume (35 $\mathrm{ml})$. However, this data was not correlated with the reduction of perioperative complications.

In attempting to make thyroidectomy an even safer and more efficient procedure, haemostatic devices were developed with the purpose of adequate haemostasis without the need for numerous ligatures, which theoretically could save time. One of the most studied is the harmonic scalpel, which consists of mechanical energy in the form of ultrasonic vibrations (up to $55,000 \mathrm{Htz}$ ) that seal the blood vessels by breaking the hydrogen and protein bonds of the tissues and vessels and creating endovascular clot $^{3,4}$. One of the theoretical benefits of using the harmonic scalpel is that it acts under lower temperatures $\left(50^{\circ} \mathrm{C}-100^{\circ} \mathrm{C}\right)$, resulting in decreased heat transfer by adjacent tissues and, consequently, less thermal trauma ${ }^{3,4}$. Moreover, it does not transmit any type of current to the patient ${ }^{3,4}$.

One of the most frequent and feared complications during thyroidectomy is injury to the inferior laryngeal nerve, which occurs due to surgical trauma, either mechanical (manipulation, traction or section) or thermal trauma. Experimental studies in pigs with histological analysis have demonstrated that the use of the ultrasonic scalpel in the dissection of adjacent tissues $(1 \mathrm{~mm})$ to the inferior laryngeal nerve does not cause thermal nerve damage $e^{44,45}$. In another experimental pig model, it was concluded that there is thermal lesion of the inferior laryngeal nerve by lateral heat dissipation in dissections that are distant $<1 \mathrm{~mm}$ from the nerve $\mathrm{e}^{46}$. The dissipation of heat to adjacent tissues is directly related to the power and time used by the harmonic scalpel. Studies show that the use of the harmonic scaler for more than 5 seconds with $4 / 5$ intensities or for more than 20 seconds with lower intensities can generate thermal trauma to the tissues ${ }^{47,48}$. In this review, no significant difference was observed in the incidence of both temporary and permanent inferior laryngeal nerve dysfunction, comparing surgeries with and without harmonic scalpel.

Voice quality is a poorly assessed outcome in clinical trials that examine the efficacy of various haemostatic devices. Two prospective randomized studies have demonstrated that there are no significant differences in voice quality (objective and subjective) of patients undergoing thyroidectomy with the aid of the harmonic scalpel compared to the conventional technique ${ }^{41,49}$.

All new technology that is developed must present, in addition to proven efficacy through comparative 
studies with proper methodology, also an economic analysis that assesses its implementation costs. For this, there are specific economic assessment tools and methodologies. Studies based on the concepts of cost-effectiveness, cost-benefit and cost-utility should be encouraged in order to obtain better information for decision-making on the incorporation or not of a new technology. In this review, the cost analysis was not considered a primary outcome and was not explored in detail, but there was a tendency to decrease costs in operations with the aid of the harmonic scalpel. This economy was mainly due to the shorter operating time observed in this group, which was directly related to lower operating room and human resources costs. A systematic review with meta-analysis on hospital costs, published in 2016, has shown that there is an absolute reduction of approximately US\$ 229 in harmonic scalpel surgeries ${ }^{50}$.
This systematic review updates the data available in the literature with published clinical trials up to the mid-2017. The clinical data found in this study are in line with the latest published reviews on the subject ${ }^{51-54}$ and show that there is apparently no doubt about the actual efficacy and safety of the harmonic scalpel, questioning only the cost-effectiveness of the implementation of this technology in thyroid surgery.

\section{CONCLUSION}

In patients submitted to total thyroidectomy, the use of the harmonic scalpel is effective, reducing operation time and intraoperative bleeding volume when compared to the conventional technique. There is no difference in the incidence of postoperative complications with the aid of the technology.

\section{REFERENCES}

1. Smith RB, Coughlin A. Thyroidectomy haemostasis. Otolaryngol Clin North Am. 2016;49(3):727-48

2. Hannan SA. The magnificent seven: a history of modern thyroid surgery. Int | Surg. 2006;4(3):187-91.

3. Manouras A, Markogiannakis HE, Kekis PB, Lagoudianakis EE, Fleming B. Novel haemostatic devices in thyroid surgery: electrothermal bipolar vessel sealing system and harmonic scalpel. Expert Rev Med Devices. 2008:5(4):447-66.

4. Dhepnorrarat RC, Witterick II. New technologies in thyroid cancer surgery. Oral Oncol. 2013;49(7):659-64

5. Jadad AR, Moore RA, Carroll D, Jenkinson C, Reynolds DI, Gavaghan D|, et al. Assessing the quality of reports of randomized clinical trials: is blinding necessary? Control Clin Trials. 1996;17(1):1-12

6. Voutilainen $\mathrm{PE}$, Haglund $\mathrm{CH}$. Ultrasonically activated shears in thyroidectomies: a randomized trial. Ann Surg. 2000;231(3):322-8.

7. Kilic M, Keskek M, Ertan T, Yoldas O, Bilgin A, Koc M. A prospective randomized trial comparing the harmonic scalpel with conventional knot tying in thyroidectomy. Adv Ther. 2007;24(3):632-8

8. Basoglu M, Ozturk G, Atamanalp SS, Aydinli B, Yildirgan MI, Oren D. The use of harmonic scalpels in thyroidectomies: clinical experiences. Eurasian Med. 2008;40(2):75-8.

9. Yener O, Demir M, Yılmaz A, Yıgıtbaşı R, Atak T. Harmonic scalpel compared to conventional haemostasis in thyroid surgery. Indian J Surg. 2014;76(1):66-9

10. Defechereux T, Meurisse M. Haemostasis and ultrasonic shears for thyroid surgery. Ann Chir. 2006;131(2):154-6.

11. Meurisse M, Defechereux T, Maweja S, Degauque C, Vandelaer M, Hamoir E. Evaluation of the Ultracision ultrasonic dissector in thyroid surgery. Prospective randomized study. Ann Chir. 2000;125(5):468-72.

12. Witzel $K$, von Rahden $B H$, Stein $H$. The effect of ultrasound dissection in thyroid surgery. Eur Surg Res. 2009;43(2):241-4

13. Marchesi M, Biffoni M, Cresti R, Mulas MM, Turriziani V, Berni A, et al. Ultrasonic scalpel in thyroid surgery. Chir Ital. 2003;55(2):299-308.
14. Defechereux T, Rinken F, Maweja S, Hamoir E, Meurisse M. Evaluation of the ultrasonic dissector in thyroid surgery. A prospective randomised study. Acta Chir Belg. 2003;103(3):274-7.

15. Ortega I, Sala C, Flor B, Lledo S. Efficacy and cost-effectiveness of the UltraCision harmonic scalpel in thyroid surgery: an analysis of 200 cases in a randomized trial. . Laparoendosc Adv Surg Tech A. 2004;14(1):9-12.

16. Cordón C, Fajardo R, Ramírez J, Herrera MF. A randomized, prospective, parallel group study comparing the Harmonic Scalpel to electrocautery in thyroidectomy. Surgery. 2005;137(3):337-41.

17. Frazzetta M, Furgiuele $G$, Raimondo D, Sammartano A, Mannino E, De Simone $G$, et al. Ultrasonic dissector for total thyroidectomy: results of prospective randomized study. G Chir. 2005;26(8-9):295-301.

18. Miccoli P, Berti P, Dionigi G, D'Agostino J, Orlandini C, Donatini G. Randomized controlled trial of harmonic scalpel use during thyroidectomy. Arch Otolaryngol Head Neck Surg. 2006;132(10):1069-73.

19. Yildirim O, Umit T, Ebru M, Bulent U, Belma $K$, Betul B, et al. Ultrasonic harmonic scalpel in total thyroidectomies. Adv Ther. 2008;25(3):260-5.

20. Lombardi CP, Raffaelli M, Cicchetti A, Marchetti M, De Crea C, Di Bidino $\mathrm{R}$, et al. The use of "harmonic scalpel" versus "knot tying" for conventional "open" thyroidectomy: results of a prospective randomized study. Langenbecks Arch Surg. 2008;393(5):627-31.

21. Sartori PV, De Fina S, Colombo G, Pugliese F, Romano F, Cesana G, et al. Ligasure versus Ultracision in thyroid surgery: a prospective randomized study. Langenbecks Arch Surg. 2008;393(5):655-8.

22. Hallgrimsson P, Lovén L, Westerdahl J, Bergenfelz A. Use of the harmonic scalpel versus conventional haemostatic techniques in patients with Grave disease undergoing total thyroidectomy: a prospective randomised controlled trial. Langenbecks Arch Surg. 2008;393(5):675-80.

23. Pons $Y$, Gauthier J, Ukkola-Pons E, Clément $P$, Roguet $E$, Poncet JL, et al. Comparison of LigaSure vessel sealing system, harmonic scalpel, and conventional haemostasis in total thyroidectomy. Otolaryngol Head Neck Surg. 2009;141(4):496-501.

24. Papavramidis TS, Sapalidis K, Michalopoulos N, Triantafillopoulou K, Gkoutzamanis G, Kesisoglou I, et al. UltraCision harmonic scalpel ver- 
sus clamp-and-tie total thyroidectomy: a clinical trial. Head Neck. 2010;32(6):723-7.

25. Miccoli P, Materazzi G, Miccoli M, Frustaci G, Fosso A, Berti P. Evaluation of a new ultrasonic device in thyroid surgery: comparative randomized study. Am | Surg. 2010;199(6):736-40.

26. Di Rienzo RM, Bove A, Bongarzoni G, Palone G, Corradetti L, Corbellin L. Comparison of conventional technique, Ligasure Precise and Harmonic Focus in total thyroidectomy. G Chir. 2010;31(6-7):296-8.

27. Gentileschi P, D'Ugo S, laculli E, Gaspari AL. Harmonic Focus ${ }^{\top M}$ versus "knot tying" during total thyroidectomy: a randomized trial. Updates Surg. 2011;63(4):277-81.

28. Mourad M, Rulli F, Robert A, Scholtes JL, De Meyer M, De Pauw L. Randomized clinical trial on Harmonic Focus shears versus clamp-and-tie technique for total thyroidectomy. Am / Surg. 2011;202(2):168-74.

29. Ferri E, Armato E, Spinato G, Spinato R. Focus harmonic scalpel compared to conventional haemostasis in open total thyroidectomy: a prospective randomized trial. Int | Otolaryngol. 2011;2011:357195.

30. Kowalski LP, Sanabria A, Vartanian JG, Lima RA, Mendonça UB, Santos $\mathrm{CR}$, et al. Total thyroidectomy with ultrasonic scalpel: a multicenter, randomized controlled trial. Head Neck. 2012;34(6):805-12.

31. Sista F Schietroma M, Ruscitti $C$, De Santis G, De Vita F Carlei F, et al. New ultrasonic dissector versus conventional haemostasis in thyroid surgery: a randomized prospective study. J Laparoendosc Adv Surg Tech A. 2012;22(3):220-4.

32. Docimo G, Ruggiero R, Gubitosi A, Casalino G, Bosco A, Gili S, et al. Ultrasound scalpel in thyroidectomy. Prospective randomized study. Ann Ital Chir. 2012;83(6):491-6

33. Ruggeri M, Dibidino R, Marchetti M, Lombardi CP, Raffaelli M, Cicchetti A. The harmonic study: cost-effectiveness evaluation of the use of the ultrasonic scalpel in total thyroidectomy. Int | Technol Assess Health Care. 2012;28(3):259-64

34. Konturek A, Barczyński M, Stopa M, Nowak W. Total thyroidectomy for non-toxic multinodular goiter with versus without the use of harmonic FOCUS dissecting shears - a prospective randomized study. Wideochir Inne Tech Maloinwazyjne. 2012;7(4):268-74.

35. Soroush AR, Pourbakhtyaran E, Allame S, Zamani MM, Etemedi M, Nasiri S. Harmonic scalpel is more secure than conventional methods in total thyroidectomy: a randomized clinical trial. J Minim Invasive Surg Sci. 2013;2(3):23-7.

36. Materazzi G, Caravaglios G, Matteucci V, Aghababyan A, Miccoli M, Miccoli P. The impact of the Harmonic FOCUS ${ }^{T M}$ on complications in thyroid surgery: a prospective multicenter study. Updates Surg. 2013;65(4):295-9.

37. Duan YF, Xue W, Zhu F, Sun DL. FOCUS harmonic scalpel compared to conventional haemostasis in open total thyroidectomy: a prospective randomized study. J Otolaryngol Head Neck Surg. 2013;42:62.

38. Zanghì A, Cavallaro A, Di Vita M, Cardi F, Di Mattia P, Piccolo G, et al. The safety of the Harmonic ${ }^{\circledR}$ FOCUS in open thyroidectomy: a prospective, randomized study comparing the Harmoni ${ }^{\circledR}$ FOCUS and traditional suture ligation (knot and tie) technique. Int J Surg. 2014;12(Suppl 1):S132-5.

39. Cannizzaro MA, Lo Bianco S, Borzì L, Cavallaro A, Buffone A. The use of FOCUS Harmonic scalpel compared to conventional haemostasis (knot and tie ligation) for thyroid surgery: a prospective randomized study. Springerplus. 2014;3:639.
40. Al-Dhahiry IK, Hameed HM Total thyroidectomy: conventional suture ligation technique versus sutureless techniques using Harmonic Scalpel or Maxium. Ann Med Surg (Lond). 2015;5:29-34.

41. Minni A, Rosati D, Cavaliere C, De Carlo A, Illuminati G, Scarano Catanzaro $V$, et al. Study on the use of focus harmonic scalpel in thyroidectomies: is it useful also in preserving voice function? Eur Rev Med Pharmacol Sci. 2016;20(17):3544-51.

42. Arslan K, Erenoglu B, Dogru O, Ovet G, Turan E, Atay A, et al. Is the superior laryngeal nerve really safe when using harmonic focus in total thyroidectomy? A prospective randomized study. Asian | Surg. 2017; pii :S1015-9584(16)30251-2

43. Blanchard C, Pattou F, Brunaud L, Hamy A, Dahan M, Mathonnet M, et al. the FOThyr Group (2017). Randomized clinical trial of ultrasonic scissors versus conventional haemostasis to compare complications and economics after total thyroidectomy (FOThyr). BJS Open, 1: 2-10. doi:10.1002/ bjs5.2.

44. Dequanter D, Lammens M, Nagy N, Shahla M, Deniz Y, Aubert C, et al. Thyroid surgery with a harmonic scalpel: an experimental study. Med Devices (Auckl). 2016;9:139-42.

45. Chávez KV, Barajas EM, Soroa F, Gamboa-Dominguez A, Ordóñez S, Pantoja JP, et al. Safety assessment of the use of ultrasonic energy in the proximity of the recurrent laryngeal nerve in a porcine model. Am I Surg. 2018;215(1):186-90.

46. Applewhite MK, White MG, James BC, Abdulrasool L, Kaplan EL, Angelos $P$, et al. Ultrasonic, bipolar, and integrated energy devices: comparing heat spread in collateral tissues. J Surg Res. 2017;207:249-54.

47. Owaki T, Nakano S, Arimura K, Aikou T. The ultrasonic coagulating and cutting system injures nerve function. Endoscopy. 2002;34(7):575-9.

48. Emam TA, Cuschieri A. How safe is high-power ultrasonic dissection? Ann Surg. 2003;237(2):186-91.

49. Uludag SS, Teksoz S, Arikan AE, Tarhan O, Yener HM, Ozcan M, et al. Effect of energy-based devices on voice quality after total thyroidectomy. Eur Arch Otorhinolaryngol. 2017;274(5):2295-302.

50. Cheng H, Soleas IM, Ferko NC, Cameron CG, Clymer JW, Amaral JF. Hospital costs associated with thyroidectomy performed with a Harmonic device compared to conventional techniques: a systematic review and meta-analysis. J Med Econ. 2016;19(8):750-8.

51. Luo Y, Li X, Dong J, Sun W. A comparison of surgical outcomes and complications between haemostatic devices for thyroid surgery: a network meta-analysis. Eur Arch Otorhinolaryngol. 2017;274(3):1269-78.

52. Cannizzaro MA, Borzì L, Lo Bianco S, Okatyeva V, Cavallaro A, Buffone A. Comparison between Focus Harmonic scalpel and other haemostatic techniques in open thyroidectomy: a systematic review and meta-analysis. Head Neck. 2016;38(10):1571-8.

53. Cheng H, Soleas I, Ferko NC, Clymer JW, Amaral JF. A systematic review and meta-analysis of Harmonic Focus in thyroidectomy compared to conventional techniques. Thyroid Res. 2015;8:15.

54. Contin P, Gooßen K, Grummich K, Jensen K, Schmitz-Winnenthal H, Büchler MW, et al. ENERgized vessel sealing systems versus CONventional haemostasis techniques in thyroid surgery - the ENERCON systematic review and network meta-analysis. Langenbecks Arch Surg. 2013:398(8):1039-56. 